\title{
The relationship between nitric oxide and cadmium toxicity in wheat (Triticum aestivum L.) seedlings
}

\author{
Songül CANAKCI GULENGUL a,* (iD, Ayse Dilek OZSAHIN K b iD, Tuba OKUTAN HAMARATa (iD \\ a Firat University, Department of Biology, TR-23000, Elazig Turkey \\ b Bitlis Eren University, Department of Biology, TR-13000, Bitlis Turkey
}

\section{A R T I C L E IN F O}

Article history:

Received 03 July 2020

Received in revised form 27 August 2020

Accepted 29 September 2020

\section{Keywords:}

Cadmium toxicity

Nitric oxide

Oxidative damage

SNP

Wheat (Triticum aestivum L.)

\begin{abstract}
In this study, biochemical responds against different cadmium concentrations ( $25 \mu \mathrm{M}, 50 \mu \mathrm{M}$ and $75 \mu \mathrm{M})$ in seedlings belonging to three wheat (Triticum aestivum L.) varieties applied to different SNP $(25 \mu \mathrm{M}$ and $50 \mu \mathrm{M}$ ) concentrations. As the material of the study, fifteen days old seedlings of wheat (Triticum aestivum L.) were used. In all applications carried out to the seedlings, hydroponic method was preferred. The seedlings were divided into three groups in which pretreatment of SNP (sodium nitroprusside) for 48 hours were done. After that, different concentrations of cadmium were applied to these three groups to except controls (pure water and SNPs). In addition, reduced glutathione (GSH) / oxidized glutathione (GSSG) ratio, catalase (CAT) with superokside glutathione (SOD) activities were detected in the leaves. According to the obtained results, (GSH) / (GSSG) ratio reduced in all three varieties; CAT activity was reduced in Bayraktar and Ikizce, but it was increased in Tosunbey. SOD activity was increased all three varieties. The most prominent responses of SOD enzyme activity in the leaves of wheat seedlings were determined in Tosunbey wheats. When the results are evaluated, generally, $50 \mu \mathrm{M}$ of SNP pre-application was found as more successful than $25 \mu \mathrm{M}$ of SNP application in terms of attenuating Cd toxicity. SNP was found to have a mitigating effect against $\mathrm{Cd}$ depending on the dose.
\end{abstract}

\section{Introduction}

Heavy metal uptake negatively affects the quality of the biological activities of plants by creating stress in the plant (Khairy et al., 2016). Intake amounts of heavy metals vary depending on plant species and age. All plants are capable of collecting mineral elements necessary for growth and development from soil and water. Many plants have the ability to accumulate some heavy metals, although their biological functions are not yet known. These heavy metals may be Cd, Cr, $\mathrm{Pb}, \mathrm{Co}, \mathrm{Ag}, \mathrm{Se}$ and $\mathrm{Hg}$ depending on the plant species. Both tolerable and accumulative upper limits of heavy metals differ in different plant species (Okçu et al., 2009). Plants have various defense mechanisms that can tolerate the damages of heavy metals such as increasing the amount of antioxidant enzyme activities and antioxidant molecules and repairing cell membranes (Verma and Dubey, 2003; Zacchini et al., 2003; Benavides et al., 2005). Cadmium is a long half-life heavy metal and is commonly found in the environment (Gill et al., 2013). Cadmium is one of the most destructive heavy metals causing stress in plants (Hegedus et al., 2001). They are much more toxic (2-20 times) than other heavy metals. Cadmium is a moving element in soil and can be easily taken by plants (Okturen Asri et al., 2007). It is known that nitric oxide acts as an antioxidant and antistress agent in plant responses to various biotic and abiotic stresses such as injury, infection, drought, low and high temperature, ultraviolet (UV), ozone in

\footnotetext{
* Corresponding author.

E-mail address: scanakci@firat.edu.tr

ORCID : 0000-0002-5731-6175
} 
plants (Neill et al., 2003). In some plants, NO promotes tissue expansion at low concentrations in leaves and roots, while they exhibit inhibitory effects at high concentrations (Hufton et al., 1996; Leshem and Haramaty, 1996). When NO reacts with active oxygen species $\left(\mathrm{H}_{2} \mathrm{O}_{2}, \mathrm{OH} \bullet \mathrm{O}_{2} \bullet, 0 \mathrm{ONO} \cdot\right.$ etc.), it shows either a toxic or protective effect. There are also indirect protective signal transduction pathways between NO and intracellular antioxidant systems such as glutathione, ascorbate, carotenoids and antioxidant enzymes (Beligni and Lamattina, 1999a, b). It has been reported that the application of $\mathrm{Cd}$ in citrus rootstocks has increased the amount of superoxide radical and hydrogen peroxide, and it has increased activities of lipoxygenase, superoxide dismutase and catalase (Jouili and El Ferjani, 2004). Nahar et al. (2016), reported that SOD and CAT activities of mung bean seedlings increased with Cd treatment compared to control, and also SNP (Sodium nitroprusside, it is nitric oxide donor)) application caused a sustained increase in SOD activities and decrease in CAT activities (Nahar, et al., 2016). It was found that NO plays a protective role against cadmium stress in sunflower leaves (Laspina et al., 2005). It has been found that increased $\mathrm{Cd}$ amount caused loss plant weight and decreased of the activity of superoxide dismutase, catalase and peroxidase enzymes in Oryza sativa (Hassan et al., 2005).

In this study, the effects of SNP pretreatment on the physiological and biochemical parameters of different $\mathrm{Cd}$ concentrations on 3 different varieties of bread wheat (Triticum aestivum L. cv Tosunbey, Bayraktar cv. and Ikizce cv.) was investigated.

\section{Test Material and Methods}

To grow the seedlings of wheat (Triticum aestivum L. cV Tosunbey, cv Bayraktar and cv Ikizce that they were obtained from Ministry Of Agriculture And Forest Field Plants Central Research Institute Directorate, Turkey), homogenous seeds were soaked with pure water and kept in the dark for 6 hours at $23-25^{\circ} \mathrm{C}$. At the end of this period, wheat seeds were arranged in germinationplatesand germinated in darkness for 23 days at $23-25^{\circ} \mathrm{C}$. Then, seedlings were added at regular intervals and equal amounts of soil solution in the long day period (16/8) until 15 days in normal daylight. 15 days old seedlings were selected as homogeneous and used as experimental material. 15 days old wheat seedlings were divided into 3 groups containing an equal number of seedlings and SNP was applied from the roots of the seedlings at different concentrations ( 25 and $50 \mathrm{mM}$ ) for 48 hours using the hydroponic method. Each group was hydroponically exposed to different concentrations of CdCl2 (25, 50 and $75 \mu \mathrm{M}$ ) prepared for 2 days. Reduced glutathione (GSH) / oxidized glutathione (GSSG) ratio, catalase (CAT) and superoxide dismutase (SOD) enzyme analyzes were performed in the seedlings of the different applications groups.

Reduced Glutathione (GSH) and Oxidized Glutathione (GSSG) analyses were performed according to Yilmaz et al., (2009). Briefly, tissues were homogenized with $10 \mathrm{mM}$ EDTA and $50 \mathrm{mM} \mathrm{NaClO}_{4}, 0.1 \% \mathrm{H}_{3} \mathrm{PO}_{4}$ mixture. For catalase enzyme activity, phosphate buffer with hydrogen peroxide obtained by adding $30 \mathrm{mM} \mathrm{H} \mathrm{O}_{2}$ to the $\mathrm{pH} 7$ phosphate buffer was used to determine the catalase activity. Analysis of catalase enzyme activity was measured based on the method of Aebi, (1984). Superoxide dismutase activity was determined according to the method developed by Mourente et al., (1999). Briefly, containing $0.5 \mathrm{ml}$ of $100 \mathrm{mM}$ potassium phosphate buffer, $0.1 \mathrm{mM}$ EDTA, $200 \mu \mathrm{l}$ adrenaline, $200 \mu \mathrm{l}$ xanthine and $50 \mu \mathrm{l}$ distilled water and $50 \mu \mathrm{l}$ sample were prepared and the reaction initiated by the addition of $10 \mu$ xanthine oxidase.

All parameters in our study were analyzed 3 times. Accuracy values of the data were tested by means of SPSS 15 software and one-way ANOVA. Differences between the groups were also differentiated at $\mathrm{p} \leq 0.05$ significance level.

\section{Results}

\subsection{Glutathione (GSH)/Oxide Glutathione (GSSG) Levels}

Compared to the control group of Reduced Glutathione (GSH) / Oxidized Glutathione (GSSG) ratio in the leaves of Tosunbey seedlings; $25 \mu \mathrm{M}$ Cd, $25 \mu \mathrm{M}$ SNP, $25 \mu \mathrm{M}$ SNP $+25 \mu \mathrm{M}$ Cd, $25 \mu \mathrm{M}$ $\mathrm{SNP}+75 \mu \mathrm{M}$ Cd and $50 \mu \mathrm{M}$ SNP $+75 \mu \mathrm{M}$ Cd groups decreased by $52.38 \%, 56.06 \%, 67.74 \%, 56.44 \%$ and $65.80 \%$ respectively. $(\mathrm{P} \leqslant 0.05)$. It was determined that Reduced Glutathione (GSH) / Oxidized Glutathion (GSSG) ratio decrased $50 \mu \mathrm{M} \mathrm{Cd}, 75 \mu \mathrm{M}$ Cd, $25 \mu \mathrm{M} \mathrm{SNP}+50 \mu \mathrm{M}$ Cd, $50 \mu \mathrm{M}$ SNP, $50 \mathrm{SNP}+25 \mu \mathrm{M}$ Cd and $50 \mu \mathrm{M}$ SNP $+50 \mu \mathrm{M}$ Cd groups compared to Control (Table 1). Although it was not statistically significant ( $p>0.05$ ) compared to the control group in the leaves of Bayraktar seedlings; in the $25 \mu \mathrm{M}$ SNP $+25 \mu \mathrm{M}$ Cd and $50 \mu \mathrm{M}$ SNP $+50 \mu \mathrm{M}$ Cd groups, a decrease of $24.72 \%$ and $7.79 \%$ was detected, respectively ( $\mathrm{P} \leqslant$ 0.05). Compared to control group, The Reduced Glutathione (GSH) / Oxidized Glutathione (GSSG) ratio was decreased by 25 $\mu \mathrm{M} \mathrm{Cd}, 50 \mu \mathrm{M}$ Cd, $75 \mu \mathrm{M}$ Cd, $25 \mu \mathrm{M}$ SNP, $25 \mu \mathrm{M}$ SNP + $50 \mu \mathrm{M} \mathrm{Cd}$, $25 \mu \mathrm{M} \mathrm{SNP}+75 \mu \mathrm{M}$ Cd, $50 \mu \mathrm{M} \mathrm{SNP}, 50 \mathrm{SNP}+25 \mu \mathrm{M}$ Cd and 50 $\mu \mathrm{M} \mathrm{SNP}+75 \mu \mathrm{M}$ treatments. These datas were also found to be statistically insignificant $(\mathrm{P}>0.05)$.

Table 1. Glutathione and oxide glutathione amounts in application groups

\begin{tabular}{lccc}
\hline \multirow{2}{*}{ GROUPS } & \multicolumn{3}{c}{ GSH / GSSG } \\
\cline { 2 - 4 } & TOSUNBEY & BAYRAKTAR & IKIZCE \\
CONTROL & $13,86 \pm 1,7$ & $8.33 \pm 0,7$ & $13,59 \pm 1,6$ \\
\hline $\mathbf{2 5} \boldsymbol{\mu M}$ SNP & $6,09 \pm 1,9^{*}$ & $7.05 \pm 0,5$ & $9,72 \pm 2,1$ \\
\hline $\mathbf{5 0} \boldsymbol{\mu M ~ S N P}$ & $11,54 \pm 5,6$ & $7.77 \pm 0,3$ & $8,75 \pm 1,4^{*}$ \\
\hline $\mathbf{2 5} \boldsymbol{\mu M} \mathbf{C d}$ & $6,61 \pm 3^{*}$ & $7.12 \pm 0,2$ & $10,78 \pm 0,4$ \\
\hline $\mathbf{5 0} \boldsymbol{\mu M} \mathbf{C d}$ & $9,12 \pm 1,8$ & $8.08 \pm 0.2$ & $10,42 \pm 0,9$ \\
\hline $\mathbf{7 5} \boldsymbol{\mu M} \mathbf{C d}$ & $7,11 \pm 2,4$ & $8.35 \pm 1,5$ & $11,63 \pm 2,5$ \\
\hline $\mathbf{2 5} \boldsymbol{\mu M ~ S N P - ~} \mathbf{2 5} \boldsymbol{\mu M}$ & $4,47 \pm 0,6^{*}$ & $6.27 \pm 0.9 *$ & $7,45 \pm 1,4^{*}$ \\
\hline $\mathbf{2 5} \boldsymbol{\mu M ~ S N P - 5 0} \boldsymbol{\mu M}$ & $9,28 \pm 2,3$ & $7.11 \pm 0,9$ & $7.79 \pm 1,5^{*}$ \\
\hline $\mathbf{2 5} \boldsymbol{\mu M ~ S N P - ~} \mathbf{7 5} \boldsymbol{\mu M}$ & $6,03 \pm 0,9^{*}$ & $7.01 \pm 0,3$ & $9,06 \pm 1,9^{*}$ \\
\hline $\mathbf{5 0} \boldsymbol{\mu M ~ S N P - 2 5} \boldsymbol{\mu M}$ & $12,25 \pm 0.9$ & $7.59 \pm 0,5$ & $8,88 \pm 0,7^{*}$ \\
\hline $\mathbf{5 0} \boldsymbol{\mu M}$ SNP-50 $\boldsymbol{\mu M}$ & $10,71 \pm 1,3$ & $7.45 \pm 0,5^{\circ}$ & $8,48 \pm 0,9^{*}$ \\
\hline $\mathbf{5 0} \boldsymbol{\mu M}$ SNP-75 $\boldsymbol{\mu M}$ & $4,74 \pm 0,7^{*}$ & $7.11 \pm 0,2$ & $7,93 \pm 1,2^{*}$ \\
\hline
\end{tabular}

*: Compared to control ${ }^{\square}$ : Intergroup; Important at $\mathrm{p} \leq 0.05$ levels. Average of data \pm SE (n: 3) 


\subsection{Catalase (CAT) Activities}

It was determined that, compared to the control group, the CAT activity of the leaves of Tosunbey seedlings; $25 \mu \mathrm{M} \mathrm{Cd}, 50 \mu \mathrm{M}$ $\mathrm{Cd}, 75 \mu \mathrm{M}$ Cd, $25 \mu \mathrm{M}$ SNP, $25 \mu \mathrm{M}$ SNP + $25 \mu \mathrm{M}$ Cd, $25 \mu \mathrm{M}$ SNP + $50 \mu \mathrm{M} \mathrm{Cd}, 50 \mu \mathrm{M}$ SNP $+25 \mu \mathrm{M}$ Cd, $50 \mu \mathrm{M}$ SNP $+75 \mu \mathrm{M} \mathrm{Cd}$ (respectively 74.02\%, 30.19\%, 21.76\%, 42.63\%, 51.17\%, $54.48 \%, 34.05 \%$ and $20.44 \%$ ) caused decrease while $50 \mu \mathrm{M}$ $\mathrm{SNP}+50 \mu \mathrm{M}$ Cd group caused an increase $(26.21 \%)(\mathrm{P} \leqslant 0.05)$. It was revealed that, compared to the control group, CAT activity in the leaves of Bayraktar seedlings, the CAT activity decreased by $25 \mu \mathrm{M} \mathrm{Cd}, 50 \mu \mathrm{M}$ Cd, $75 \mu \mathrm{M}$ Cd, $25 \mu \mathrm{M}$ SNP+25 $\mu \mathrm{M}$ $\mathrm{Cd}, 25 \mu \mathrm{M}$ SNP+50 $\mu \mathrm{M}$ Cd, $25 \mu \mathrm{M}$ SNP+75 $\mu \mathrm{M} \mathrm{Cd}, 50 \mu \mathrm{M}$ SNP+50 $\mu \mathrm{M}$ Cd ve $50 \mu \mathrm{M}$ SNP+75 $\mu \mathrm{M}$ Cd groups (respectively $\%$ 14.16, \% 26.64, \% 29.79, \% 10.23 , \% 23.96, \% 29.75, \% 26.84 and $\% 43.28$ ) while $50 \mu \mathrm{M}$ SNP+25 $\mu \mathrm{M}$ Cd group caused an increase $(7.75 \%)(\mathrm{P}>0.05)$. It was found that CAT activity of the leaves of T. aestivum L. cv

Ikizce seedlings decreased by $25 \mu \mathrm{M}$ Cd, $50 \mu \mathrm{M} \mathrm{Cd}, 75 \mu \mathrm{M} \mathrm{Cd}$, , $25 \mu \mathrm{M}$ SNP+25 $\mu \mathrm{M}$ Cd, $25 \mu \mathrm{M}$ SNP+50 $\mu \mathrm{M}$ Cd, $25 \mu \mathrm{M}$ SNP+75 $\mu \mathrm{M}$ Cd, $50 \mu \mathrm{M}$ SNP+50 $\mu \mathrm{M}$ Cd ve $50 \mu \mathrm{M}$ SNP+75 $\mu \mathrm{M}$ Cd gropus (respectively 11.99\%, 17.21\%, 21.74\%, 22.88\%, 22.35\%, $21.96 \%, 25.10 \%$ and $39.86 \%$ ) also $50 \mu \mathrm{M}$ SNP and it increased by $50 \mu \mathrm{M} \mathrm{SNP}+25 \mu \mathrm{M}$ Cd groups ( respectively $7.04 \%$ and $28.07 \%)$ when compared to the control $(\mathrm{P} \leq 0,05)$.

Table 2. Catalase activities in application groups

\begin{tabular}{|c|c|c|c|}
\hline \multirow{2}{*}{ GROUPS } & \multicolumn{3}{|c|}{ CAT Activities $(\mu \mathrm{g} / \mathrm{g})$} \\
\hline & TOSUNBEY & BAYRAKTAR & IKIZCE \\
\hline CONTROL & $357.63 \pm 1.2$ & $420.03 \pm 5.0$ & $629.73 \pm 5.1$ \\
\hline $25 \mu \mathrm{M}$ SNP & $510.09 \pm 0.5^{*}$ & $421.84 \pm 5.9$ & $628.51 \pm 10.4$ \\
\hline $50 \mu \mathrm{M}$ SNP & $365.26 \pm 20.9$ & $449.01 \pm 15.6$ & $674.07 \pm 24.9^{*}$ \\
\hline $25 \mu \mathrm{M} \mathrm{Cd}$ & $622.37 \pm 3.8^{*}$ & $360.51 \pm 15.2^{*}$ & $554.18 \pm 20.9 *$ \\
\hline $50 \mu \mathrm{M} \mathrm{Cd}$ & $465.60 \pm 6.1^{*}$ & $308.08 \pm 3.1^{*}$ & $521.35 \pm 9.3^{*}$ \\
\hline $75 \mu \mathrm{M} \mathrm{Cd}$ & $435.47 \pm 15.5^{*}$ & $294.87 \pm 6.3^{*}$ & $492.81 \pm 15.1^{*}$ \\
\hline $25 \mu \mathrm{M}$ SNP- $25 \mu \mathrm{M}$ Cd & $540.63 \pm 0.8^{* \square}$ & $377.01 \pm 5.4^{*}$ & $485.61 \pm 4.3^{* \square}$ \\
\hline $25 \mu \mathrm{M}$ SNP-50 $\mu \mathrm{M}$ & $552.48 \pm 1.1^{* \square}$ & $319.34 \pm 6.1^{*}$ & $488.96 \pm 13.0^{*}$ \\
\hline $25 \mu \mathrm{M}$ SNP- $75 \mu \mathrm{M}$ & $365.16 \pm 7.3^{\square}$ & $295.03 \pm 7.2^{*}$ & $491.38 \pm 9.2^{*}$ \\
\hline $50 \mu \mathrm{M}$ SNP- $25 \mu \mathrm{M}$ & $479.43 \pm 7.8^{* \square}$ & $452.59 \pm 2.1 * \square$ & $452.94 \pm 16.4$ *ロ \\
\hline $50 \mu \mathrm{M}$ SNP-50 $\mu \mathrm{M}$ & $451.38 \pm 29.3^{*}$ & $307.26 \pm 0.8^{*}$ & $471.66 \pm 20.1^{* \square}$ \\
\hline $50 \mu M$ SNP-75 $\mu M$ & $284.50 \pm 4.7^{* \square}$ & $238.22 \pm 26.7^{* \square}$ & $378.67 \pm 3.2^{* \square}$ \\
\hline
\end{tabular}

*: Compared to control ${ }^{\square}$ : Intergroup; Important at $\mathrm{p} \leq 0.05$ levels. Average of data \pm SE (n: 3)

\subsection{Superoxide Dismutase (SOD) Activities}

It was observed that SOD activity in the leaves of Tosunbey seedlings compared to control; $50 \mu \mathrm{M} \mathrm{Cd}, 75 \mu \mathrm{M} \mathrm{Cd}, 25 \mu \mathrm{M}$ SNP $+25 \mu \mathrm{M}$ Cd, $25 \mu \mathrm{M}$ SNP + $50 \mu \mathrm{M}$ Cd, $25 \mu \mathrm{M}$ SNP + $75 \mu \mathrm{M} \mathrm{Cd}, 50$ $\mu \mathrm{M}$ SNP $+50 \mu \mathrm{M}$ Cd and $50 \mu \mathrm{M}$ SNP $+75 \mu \mathrm{M}$ Cd respectively ; $20.94 \%, 32.93 \%, 29.90 \%, 15.01 \%, 22.39 \%, 20.94 \%$ and $19.49 \%$ increase; A decrease of $17.52 \%$ was detected in the 50 $\mu \mathrm{M}$ SNP treatment group $(\mathrm{P} \leqslant 0.05)$.

Compared to the control group, SOD activities in the leaves of Bayraktar seedlings; it was observed an increase in the $25 \mu \mathrm{M}$ Cd, $50 \mu \mathrm{M}$ Cd, $75 \mu \mathrm{M}$ Cd, $25 \mu \mathrm{M}$ SNP, $25 \mu \mathrm{M}$ SNP + $25 \mu \mathrm{M}$ Cd, 25 $\mu \mathrm{M}$ SNP + $50 \mu \mathrm{M}$ Cd, $25 \mu \mathrm{M}$ SNP + $75 \mu \mathrm{M}$ Cd, $50 \mu \mathrm{M}$ SNP, $50 \mu \mathrm{M}$
$\mathrm{SNP}+25 \mu \mathrm{M} \mathrm{Cd}, 50 \mu \mathrm{M} \mathrm{SNP}+50 \mu \mathrm{M}$ Cd and $50 \mu \mathrm{M} \mathrm{SNP}+75$ $\mu \mathrm{M} C d$ treatments, but these increases were not found statistically significant ( $\mathrm{p}>0.05)$.

SOD activity in the leaves of Ikizce seedlings when compared to control group it was determined that, increased ratio of $7.07 \%$ in $50 \mu \mathrm{M}$ SNP $+50 \mu \mathrm{M}$ Cd group (P \%0.05). Also, an increase was found in the $25 \mu \mathrm{M} \mathrm{Cd}, 50 \mu \mathrm{M}$ Cd, $75 \mu \mathrm{M}$ Cd, $25 \mu \mathrm{M}$ SNP, 25 $\mu \mathrm{M} \mathrm{SNP}+25 \mu \mathrm{M}$ Cd, $25 \mu \mathrm{M} \mathrm{SNP}+50 \mu \mathrm{M}$ Cd, $25 \mu \mathrm{M}$ SNP +75 $\mu \mathrm{M} \mathrm{Cd}, 50 \mu \mathrm{M}$ SNP, $50 \mu \mathrm{M}$ SNP $+25 \mu \mathrm{M}$ Cd and $50 \mu \mathrm{M}$ SNP +75 $\mu \mathrm{M}$ Cd groups, but it was not found statistically significant $(\mathrm{P}>$ 0.05).

Table 3. Superoxide Dismutase activities in application groups

\begin{tabular}{|c|c|c|c|}
\hline \multirow{2}{*}{ GROUPS } & \multicolumn{3}{|c|}{ CAT Activities ( $\mu \mathrm{g} / \mathrm{g})$} \\
\hline & TOSUNBEY & BAYRAKTAR & IKIZCE \\
\hline CONTROL & $7.59 \pm 0.7$ & $12.01 \pm 0.1$ & $14.71 \pm 0.3$ \\
\hline $25 \mu M$ SNP & $8.2 \pm 0.2$ & $12.27 \pm 1.1$ & $14.64 \pm 0.5$ \\
\hline $50 \mu M$ SNP & $6.268 \pm 0.3^{*}$ & $12.24 \pm 0.2$ & $14.92 \pm 0.3$ \\
\hline $25 \mu \mathrm{M} \mathrm{Cd}$ & $7.71 \pm 0.1$ & $12.19 \pm 0.1$ & $15.19 \pm 0.2$ \\
\hline $50 \mu \mathrm{M} \mathrm{Cd}$ & $9.18 \pm 0.3^{*}$ & $12.15 \pm 0.1^{*}$ & $15.08 \pm 0.3$ \\
\hline $75 \mu \mathrm{M} \mathrm{Cd}$ & $10.09 \pm 1.3^{*}$ & $12.39 \pm 0.2$ & $14.71 \pm 0.2$ \\
\hline $25 \mu M$ SNP- $25 \mu M$ & $9.86 \pm 0.3^{* \square}$ & $11.98 \pm 0.1$ & $15.43 \pm 0.3^{\square}$ \\
\hline $25 \mu \mathrm{M} \mathrm{SNP-50} \mu \mathrm{M}$ & $8.73 \pm 0.2^{*}$ & $12.25 \pm 0.1$ & $15.16 \pm 0.9$ \\
\hline $25 \mu \mathrm{M}$ SNP- $75 \mu \mathrm{M}$ & $9.29 \pm 0.4^{*}$ & $12.35 \pm 0.3$ & $15.05 \pm 0.3$ \\
\hline $50 \mu \mathrm{M} \mathrm{SNP-25} \mu \mathrm{M}$ & $8.62 \pm 0.2$ & $12.25 \pm 0.1$ & $14.88 \pm 0.3$ \\
\hline $50 \mu M ~ S N P-50 \mu M$ & $9.18 \pm 0.1^{*}$ & $12.43 \pm 0.3$ & $15.73 \pm 0.3^{*}$ \\
\hline $50 \mu \mathrm{M}$ SNP-75 $\mu \mathrm{M}$ & $9.07 \pm 0.7^{*}$ & $12.05 \pm 0.1$ & $15.15 \pm 0.1$ \\
\hline
\end{tabular}

\section{Discussion}

It has been determined that the most obvious reactions of the wheat seedlings in terms of GSH / GSSG ratios are given by İkizce wheat. There is information in the literature that GSH / GSSG ratios are significantly decreased in seedlings without SNP pre-treatment (Romero-Puertas et al., 2007) and SNP preapplied (Nahar et al., 2016). In this regard, the effort of SNP pretreatment to alleviate the destructive effect of CD was found to be significant at $50 \mu \mathrm{M}$ compared to $25 \mu \mathrm{M}$. GR, a glutathione reductase enzyme, converts oxidized glutathione (GSSG) to reduced glutathione (GSH) through a reaction related to $\mathrm{NADPH}^{+}$. Reduced glutathione is an important non-enzymatic antioxidant that plays a role in defending against oxidative stress. GSH and GR form the compounds of ascorbateglutathione metabolism, which plays a role in responding to stress in plants (Kaya and Doğanlar, 2016).

It has been determined that the most prominent responses in the leaves of wheat seedlings in terms of CAT enzyme activity are given by İkizce wheat. Compared to control seedlings, seedlings without SNP pre-application (Hassan et al., 2005; Kotapati et al., 2016; Nahar et al., 2016; Liang et al., 2018) and SNP pre-applied (Kaya and Ashraf, 2015) caused decreased CAT enzyme activity. The effort of SNP pretreatment to alleviate the destructive effect of CD was found significant at 50 
$\mu \mathrm{M}$ compared to $25 \mu \mathrm{M}$. Similar results were seen in Bayraktar seedlings. It was determined that without SNP pre-application (Chaudhary and Sharma, 2009; Jouili and El Ferjani, 2004), or SNP pre-applied (Nahar et al., 2016; Ali et al., 2017; Amooaghaie et al., 2017) in Tosunbey seedlings an increase CAT activity compared to the control group, and also in the Tosunbey seedlings an increase CAT activity in $25 \mu \mathrm{M}$ SNP, and $50 \mu \mathrm{M}$ SNP in İkizce seedlings were observed. Catalase is found in organelles called peroxidase in all cells of plants and plays a protective role by keeping $\mathrm{H}_{2} \mathrm{O}_{2}$ level at a certain level for the cell. Catalase enzyme detoxifies $\mathrm{H}_{2} \mathrm{O}_{2}$ in high concentrations and provides the plant to get rid of stress with minimum damage. Increased activity of antioxidant enzymes such as CAT is as a result of the detoxification mechanism that enables lipid peroxidation to be reduced (Santos and Silva, 2015).

It was determined that the most prominent responses of the wheat seedlings in terms of SOD enzyme activities were given by Tosunbey wheat. SOD enzyme activities increased in both seedlings, without SNP pre-application (Jouili and El Ferjani, 2004) and SNP pre-applied (Nahar et al., 2016; Liang et al., 2018) compared to control seedlings. Similar results were observed in Bayraktar and İkizce wheat. The effort of SNP pretreatment in Tosunbey seedlings to alleviate the destructive effect of $\mathrm{Cd}$ was found significant at $25 \mu \mathrm{M}$ compared to $50 \mu \mathrm{M}$. $50 \mu \mathrm{M}$ SNP application was found to be significant in Tosunbey seedlings compared to control.

The antioxidant system plays an important role in protecting cell compounds from the damage of reactive oxygen species produced under stress. The increase in the production and accumulation of reactive oxygen species in plant cells under optimal growth conditions brings disruption of cellular homeostasis (Wang et al., 2015). Increasing SOD activity under stress conditions shows that superoxide radical reactive oxygen species are produced more. Because SOD plays a role in removing the superoxide radical from chloroplasts and converting it into H2O2 (Santos and Silva, 2015).

\section{Conclusion}

In this study, we observed that $\mathrm{Cd}$, which is not a necessary element for plants, is toxic for wheat plants even at very low concentrations. It was found that SNP had a mitigating effect against Cd depending on the dose. Results showed that; SNP can regulate the oxidative stress caused by $\mathrm{Cd}$ on certain parameters to a limited extent. This state is depending on the chosen concentrations, planned application and duration. However, we believe that the different studies to be carried out will contribute to the fully understanding of the subject since the studies on this subject are limited and inadequate.

\section{References}

Aebi, H., 1984. Catalase in Vitro, Method Enzym, 105,121-126.

Amooaghaie, R., Faezeh, Z.M., and Shekoofeh, E., 2017. Role of twosided crosstalk between $\mathrm{NO}$ and $\mathrm{H} 2 \mathrm{~S}$ on improvement of mineral homeostasis and antioxidative defense in Sesamum indicum under lead stress. Ecotoxicology and Environmental Safety. 139. 210-218. 10.1016/j.ecoenv.2017.01.037.
Beligni, M.V., and Lamattina, L., 1999a. Nitric oxide counteracts cytotoxic processes mediated by reactive oxygen species in plant tissues, Planta, 208, 337-344.

Beligni, M.V., and Lamattina, L., 1999b. Is nitric oxide toxic or protective, Trends Plant Sci., 4, 299-300.

Benavides, M.P., Gallego, S.M., and Tomaro, M.L., 2005. Cadmium toxicity in plants, Braz. J. Plant Physiol., 17 (1), 21-34.

Chaudhary, S., and Sharma Y.K., 2009. Interactive studies of potassium and copper with cadmium on seed germination and early seedling growth in maize (Zea mays L.), Journal of Environmental Biology, 30, 427-432.

Gill, S.S., Hasanuzzaman, M., Nahar, K., Macovei, A., and Tuteja, N., 2013. Importance of nitric oxide in cadmium stress tolerance in crop plants, Plant Physiology and Biochemistry, 63,254-261.

Hassan, M.J., Shao, G., and Zhang, G., 2005. Influence of Cadmium Toxicity on Growth and Antioxidant Enzyme Activity in Rice Cultivars with Different Grain Cadmium Accumulation, Journal of Plant Nutrition, 28 (7),1259-1270.

Hegedus, A., Erdei, S., and Horváth, G., 2001. Comparative Studies of $\mathrm{H}_{2} \mathrm{O}_{2}$ Detoxifying Enzymes in Green and Greening Barley Seedings under Cadmium Stress, Plant Science, 160, 1085 -1093.

Hufton, C.A., Besford, R.T., and Wellburn, A.R., 1996. Effects of NO $\left(+\mathrm{NO}_{2}\right)$ pollution on growth, nitrat reductase activities and associated protein contents in glasshouse lettuce grown hydroponically in winter $\mathrm{CO}_{2}$ enrichment, New Phytologist, 133, 495-501.

Jouili, H., and El Ferjani, E., 2004. Effects of copper excess on superoxide dismutase, catalase and peroxidase activities in sunflower seedlings (Helianthus anuus L.), Acta Physiologiae Plantarum, 26, 2935.

Kaya, A., and Doganlar, Z.B. 2016. Exogenous jasmonic acid induces stres tolerance in tobacco(Nicotiana tabacum) exposed to imazapic. Ecotoxicol. \& Environ. Safety, 124, 470-479.

Kaya, C., Ashraf, M. 2015. Exogenous application of nitric oxide promotes growth and oxidative defense system in highly boron stressed tomato plants bearing fruit. Sci Hortic 185: 43-47.

Khairy, A.I., Oh, M.J., Lee, S.M., Kim, D.S., and Roh, K.S., 2016. Nitric oxide overcomes $\mathrm{Cd}$ and $\mathrm{Cu}$ toxicity in in vitro-grown tobacco plants through increasing contents and acitvities of rubisco and rubisco activase, Biochimie Open, 2,41-51.

Kotapati, K.V., Palaka, B.K., and Ampasala, D.R., 2017. Alleviation of nickel toxicity in finger millet (Eleusine coracana L.) germinating seedlings by exogenous application of salicylic acid and nitric oxide Crop J, 5: 240-250.

Laspina, N.V., Groppa, M.D., Tomaro, M.L., and Benavides, M.P., 2005. Nitric oxide protects sunflower leaves against $\mathrm{Cd}$ - induced oxidative stress, Plant Science, 168 (7), 252-260.

Leshem, Y.Y., and Haramaty, E., 1996. The Characterisation and Contrasting Effects of the Nitric Oxide Free Radical in Vegetative Stress and Senescence of Pisum sativum L. Foliage, Journal of Plant Physiology, 148, 258-263.

Liang, Y., Zheng, P., Li, S., Li, K., and Xu, H., 2018. Nitrate reductase dependent $\mathrm{NO}$ production is involved in $\mathrm{H}_{2} \mathrm{~S}$ - induced nitrase stress tolerance in tomato via activation of antioxidant enzymes, Scientia 
Horticulturae, 229, 207- 214.

Mourente, G., Tocher, D., R., Diaz, E., Grau, A., and Pastor, E., 1999. Relationships between antioxidants, antioxidant enzyme activities and lipid peroxidation products during early development in Dentex eggs and larvae, Aquaculture, 179,309-324.

Nahar, K., Hasanuzzaman, M., Alam, M., Rahman, A., Suzuki, T., and Fujita, M., 2016. Polyamine and nitric oxide crosstalk: Antagonistic effests on cadmium toxicity in mung bean plants through upregulating the metal detoxification, antioxidant defense and methyglyoxal detoxification systems, Ecotoxicology and Environmental Safety, 126, 245-255.

Neill, S.J., Desikan, R., and Hancock, J.T., 2003. Nitric Oxide Signalling in Plants, New Phytologist, 159, 1469-1481.

Okcu, M., Tozlu, E., Kumlay, A.M., and Pehluvan, M., 2009. Alınteri Dergisi, 17 (B), 14-26, ISSN, 1307-3311.

Okturen Asri, F., Sonmez, S. ve Citak, S., 2007. Kadmiyumun çevre ve insan sağlığı üzerine etkileri, Batı Akdeniz Tarımsal Araștırma Enstitüsü/ANTALYA, Akdeniz Üniversitesi Ziraat Fakültesi Toprak Bölümü/ ANTALYA. http://batem.gov.tr/yayinlar/derim/2007/3239.pdf.

Romero-Puertas, M.C., Corpas, F.J., Rodríguez-Serrano, Gómez, M., del Rio, L.A., and Sandalio, L.M., 2007. Differential expression and regulation of antioxidative enzymes by cadmium in pea plants, Journal of Plant Physiology, 164, 1346-1357.

Santos, C.M., and Silva, M.A., 2015. Physiological and biochemical responses of sugarcane to oxidative stress induced by water deficit and paraquat, Acta Physiol. Plant, 37, 172.

Verma S., and Dubey R.S., 2003. Lead toxicity induces lipid peroxidation and alters the activities of antioxidant enzymes in growing rice plants, Plant Sci., 164, 645-655.

Wang, Q., Que, X., Zheng, R., Pang, Z., Li, C. and Xiao, B., 2015. Phytotoxicity assessment of atrazine on growth and physiology of three emergent plants, Environ Sci Pollut Res, 22, 9646-9657.

Yilmaz, O., Keser, S., Tuzcu, M., Guvenc, M., Cetintaş, B., İrtegun, S., Tastan, H. ve Sahin, K., 2009. A Practical HPLC Method to Measure Reduced (GSH) and Oxidized (GSSG) Glutathione Concentrations in Animal Tissues, Journal of Animal and Veterinary Advances, 8 (2), 343347.

Zacchini, M., Rea, E., Tullio, M. ve Agazio, M., 2003. Increased antioxidative capacity in maize calli during and after oxidative stress induced by a long lead treatment, Plant Physiol. Bioch., 41, 49-54. 